\title{
PTPRC Gene Product
}

National Cancer Institute

\section{Source}

National Cancer Institute. PTPRC Gene Product. NCI Thesaurus. Code C118491.

A protein encoded by the human PTPRC gene. 